\title{
ANALISIS ETIKA KERJA BERBASIS ISLAM PADA BANK SYARIAH DI KOTA MEDAN
}

\author{
Jufrizen \\ Fakultas Ekonomi Universitas Muhammadiyah Sumatera Utara \\ jufrizenumsu@gmail.com
}

\begin{abstract}
ABSTRAK
Penelitian bertujuan untuk menganalisis pandangan karyawan-karyawan tentang etika kerja Islam pada Bank Syariah di Kota Medan dan menganalisis pandangan para pimpinan tentang etika kerja Islam pada Bank Syariah di Kota Medan serta menganalisis rancangan model etika kerja Islam untuk perbankan Syariah. Kesimpulan dari penelitian ini adalah Pertama, Pandangan karyawan-karyawan tentang etika kerja menurut pandangan Islam pada Bank Syariah di Kota Medan. Karyawan beranggapan bahwa etika kerja pada Bank Syariah di Kota Medan dianggap cukup baik, maka nilainilai etika kerja Islam tersebut semua digunakan untuk melaksanakan perintah Allah SWT. Kedua, Pandangan para pimpinan tentang etika kerja Islam pada Bank Syariah di Kota Medan. Bahwa menjadi seorang pemimpin harus berdasarkan Al-Qur'an dan Hadist karena sebagai pedoman hidup dan mengikuti sifat-sifat Rasulullah SAW agar menciptakan pemimpin Islam yang sesuai dengan Syariah. Ketiga, model etika kerja Islam. Model etika kerja Islam untuk perbankan Syariah yang dirumuskan ialah input (agama, manusia, lingkungan sosial), proses (mengamalkan nilai-nilai yakni mengatur waktu, moralitas yang bersih (ikhlas), disiplin, konsekuen dan berani menghadapi tantangan, sikap percaya diri, kreatif, bertanggung jawab, berbahagia, memiliki harga diri, berjiwa kepemimpinan, berorientasi ke masa depan, berhemat, keinginan mandiri, mencari ilmu, tangguh, berorientasi produktivitas, silaturahim, kejujuran atau shiddiq, kecerdasan atau fathanah, dapat dipercaya atau amanah, menyampaikan atau tabligh), dan output (kinerja, kepuasan kerja, dan komitmen).
\end{abstract}

Kata kunci : etika kerja Islam, etika kerja Islam

\section{PENDAHULUAN}

Bekerja adalah suatu bentuk Ibadah yang dilakukan di dunia. Bekerja dengan etika kerja yang benar sesuai ajaran Islam merupakan syarat mutlak untuk dapat mencapai kebahagiaan di dunia dan di akhirat. Dalam Islam, dengan etika yang benar, baik atau dengan kata lain berakhlak dalam bekerja dapat meningkatkan ketakwaan kepada Allah SWT. Etika dalam pandangan konvensional adalah seperangkat nilai tentang baik, buruk, benar dan salah yang berdasarkan prinsip-prinsip moralitas, 
khususnya dalam perilaku dan tindakan. Sehingga etika adalah salah satu faktor penting bagi terciptanya kondisi kehidupan manusia yang lebih baik (Arifin, 2007). Sementara etika kerja dalam Islam pada hakikatnya merupakan bagian dari konsep Islam tentang manusia, karena etika kerja ialah bagian dari proses eksistensi diri manusia dalam lapangan kehidupan yang amat luas dan kompleks. Dengan demikian etika kerja ialah rajutan nilai-nilai yang membentuk kepribadian seseorang dalam bekerja (Asy'arie, 2005).

Etika kerja dalam Islam bertujuan membentuk pribadi individu yang sukses baik di dunia maupun di akhirat (Kadir, 2009). Etika kerja dalam Islam merupakan hal yang sangat penting dan mendasar karena dengan etika kerja umat Islam akan mampu mewujudkan apa yang diinginkannya sebagai bekal hidup di akhirat. Hal inilah yang mengakibatkan betapa mahal nilai etika kerja sehingga Islam sangat menghargai orangorang yang mempunyai karakter etika kerja yang tinggi sesuai dengan ajaran Islam (Djakfar, 2012).

Ada beberapa pertimbangan, mengapa kita perlu membangun etika bekerja. Diantaranya sebagai berikut: 1). Kita sangat mendambakan produk ekonomi yang sehat melalui tangan-tangan pekerja yang baik; 2). Memasuki era persaingan pasar global, bukan saja keterampilan yang menjadi andalan utama, tetapi juga sikap untuk meraih keunggulan kompetitif; 3). Gaya hidup manusia dalam era globalisasi sangat di tentukan oleh seberapa besar penghasilan seseorang dalam bekerja. Kebaikan semu dalam memperoleh penghasilan yang membentuk mentalitas manusia sombong perlu dikendalikan; 4). Batas antara halal dan haram semakin menipis, sehingga bukan mustahil orang yang akan menghalalkan segala cara untuk memperoleh penghasilan; 5). Penghasilan yang kita peroleh bukan hanya di nikmati di dunia saja, tetapi juga akan di pertanggung jawabkan kepada tuhan di alam baqa' akhirat (Luth, 2001).

Pembicaraan di atas menunjukkan pentingnya etika kerja khususnya dalam pandangan Islam. Namun demikian, dalam penelitian pendahuluan, penulis mengidentifikasi beberapa permasalahan etika kerja Islam pada Bank Syariah di Kota Medan. Masih ada beberapa hal terkait dengan etika kerja yang masih menunjukkan adanya masalah atau ketidaksempurnaan,antara lain: 1) Karyawan masih ada yang tidak menerapkan etika kerja Islam dengan baik, sehingga kurang dapat di terima di perusahaan; 2) Kurangnya keramahan dalam menyambut pengunjung atau nasabah yang datang sehingga pelanggan merasa kurang nyaman dalam bertransaksi, sementara Islam mengajarkan agar bersikap sopan dan berlemah lembut kepada orang lain; 3) Masih adanya karyawan yang tidak memberi atau mengucapkan salam kepada pengunjung atau nasabah yang datang, sementara Islam menganjurkan agar mengucapkan salam saat bertemu dengan sesama muslim; 4) Jilbab yang digunakan karyawan masih terlihat belum benar-benar Islami sesuai ajaran Islam.

Permasalahan-permasalahan etika di atas sebenarnya disebabkan banyak faktor. Ada lima pokok yang mempengaruhi etika kerja, antara lain: 1). Iman, kepercayaan dan kesetiaan kita kepada Allah; 2). Tabiat atau sifat-sifat batin; 3). Orang-orang lain atau lingkungan sosial yaitu pandangan masyarakat tentang baik dan buruk; 4). Normanorma atau hukum-hukum moral; 5). Unsur-unsur situasi (Brownlee, 2006).

Berdasarkan permasalahan-permasalahan di atas maka penulis tertarik untuk meneliti etika kerja menurut pandangan Islam pada Bank Syariah di Kota Medan. Selain permasalahan-permasalahan tersebut di atas, ketertarikan penulis untuk mengkaji etika kerja dalam pandangan Islam adalah karena pentingnya umat Islam menggali ilmu 
pengetahuan berdasarkan sumber Islam itu sendiri atau dikenal dengan istilah islamisasi ilmu pengetahuan.

Islamisasi ilmu pengetahuan mesti diupayakan semaksimal mungkin agar dapat menyelamatkan umat Islam dari penyelewengan-penyelewengan penerapan sains dari Barat yang umumnya anti religious atau memisahkan agama dengan ilmu (Qomar, 2007). Bahkan di berbagai perguruan tinggi Islam, paham-paham dan pemikiran Barat membongkar asas-asas Islam, juga terang-terangan melecehkan Islam, serta mendapat dukungan yang luas dari kalangan dosen dan mahasiswa perguruan tinggi Islam (Husaini, 2005). Menurut Imam Ghazali, apabila ilmu dan karya-karya yang dimiliki non-Muslim dianggap lebih baik dan lebih utama daripada yang dimiliki kaum muslimin, kaum muslimin berdosa dan kelak mereka akan dituntut atas kelalaian itu (Yusanto \& Widjajakusuma, 2002)

\section{LANDASAN TEORI}

\section{Etika Kerja dalam Perspektif Konvensional}

Bagian ini penulis menyajikan konsep-konsep ilmiah mengenai etika kerja dalam perspektif konvensional. Konsep-konsep yang disajikan ialah tentang pengertian, peran penting, faktor-faktor, dan nilai-nilai etika kerja menurut perspektif konvensional.

Dalam suatu kegiatan atau aktivitas kerja etika kerja merupakan hal yang paling sering dilihat dalam organisasi atau perusahaan karna meliputi bagaimana kebiasaan, tindakan atau tingkah laku seseorang atau kelompok dalam melakukan sesuatu.

Etika berasal dari kata ethos yakni pedoman, moral, dan prilaku, atau dikenal pula etiket yang artinya cara bersopan santun (Djakfar, 2012). Etika juga bermakna nilai moral seseorang atau kelompok manusia yang membimbing tindak tanduk dan sikap kelakuannya. Nilai moral manusia membimbing orang berbuat baik benar dan patuh (Salim, 2000).

Secara khusus, etika tersebut diistilahkan dengan etika kerja. Etika kerja berarti roh profesionalisme, karena pekerjaan yang dilakukan sesuai dengan etika memungkinkan terselenggaranya hubungan yang menghargai dan meningkatkan harkat dan martabat manusia sebagai manusia (Harega, 2004). Etika kerja juga bermakna norma budaya yang menggalakan pekerja menjalankan kewajibannya bekerja dengan rasa penuh tanggung jawab. Etika kerja menjadi asas kepada kepercayaan bahwa kepercayaan itu sendiri memiliki nilai intrinsik seperti membawa kemuliaan (Rashid, Husin, \& Othman, 2006).

Beberapa pengertian etika kerja menurut pandangan konvensional seperti di atas semuanya memaknai bahwa etika kerja ialah norna atau nilai-nilai seseorang atau kelompok bagaimana seharusnya mengatur suatu tindakan atau tingkah lakunya dalam kegiatan atau aktivitas kerja.

Etika kerja bermanfaat untuk pekerja sekaligus untuk organisasi tempat bekerja. Secara umum, kerja yang beretika akan menghasilkan pekerjaan yang berprestasi atau produktif. Etika kerja harus dimiliki oleh setiap pegawai karena organisasi sangat membutuhkan kerja keras dan komitmen yang tinggi dari setiap pegawai, kalau tidak organisasi akan sulit berkembang, dan memenangkan persaingan dalam merebut pangsa pasarnya (Tampubolon, 2007).

Beberapa pendapat mengenai bagaimana etika kerja berperan, berguna atau berfungsi penting salah satunya adalah: 1). Pendorong timbulnya perbuatan; 2). Penggairah dalam aktivitas; 3). Penggerak, seperti mesin bagi mobil besar kecilnya motivasi akan menentukan cepat lambatnya suatu perbuatan (Rusyan, 1989). 
Organisasi perusahaan mengembangkan nilai-nilai atau etika adalah karena beberapa alasan berikut ini: 1). Memperlakukan orang lain dengan bermartabat, terhormat, dan cinta; 2). Menempatkan manusia sebagai basis perilaku etis; 3). Menyadari bahwa segala sesuatu yang ada saling tergantung dan terkait alam, binatang dan manusia; 4). Melihat organisasi, komunitas, negara, dan dunia sebagi satu (Hendrawan, 2009).

Etika kerja dalam berbagai literatur di atas menunjukkan perannya terhadap berbagai hal dalam organisasi khususnya organisasi perusahaan. Etika kerja yang dibudayakan dengan baik akan memberikan keuntungan positif bagi perusahaan terutama dalam mendukung pencapaian tujuan. Munculnya sikap-sikap yang tidak beretika dalam bekerja seperti pemalas, tidak berdisiplin, tidak menghargai orang lain, mengabaikan tanggung jawab bekerja dapat bersumber dari berbagai faktor dari dalam dan luar diri karyawan. Pendapat ahli ada menyatakan bahwa faktor-faktor yang mempengaruhi etika kerja yaitu: keperluan kehidupan, nilai hidup, undang-undang, pendidikan, agama, dan budaya kerja (Yusoff, 2003).

Faktor-faktor lainnya yang juga mempunyai pengaruh terhadap etika seseorang antara lain: 1). Faktor agama dan adat istiadat. Setiap karyawan disarankan memahami nilai-nilai yang diyakini maupun kaidah agama yang dianutnya; 2). Faktor sosial, faktor ini antara lain meliputi perilaku sosial dan budaya, ilmu pengetahuan dan teknologi, hukum dan peraturan perundang-undangan; 3). Faktor ilmu pengetahuan dan teknologi, pada era abad ke-20 ini, manusia telah berhasil mencapai tingkat kemajuan ilmu pengetahuan dan teknologi yang belum dicapai manusia pada abad sebelumnya; 4). Faktor legislasi dan keputusan yuridis, legislasi merupakan jaminan tindakan menurut hukum sehingga orang yang bertindak tidak sesuai hukum dapat menimbulkan suatu konflik (Priharjo, 2006).

Pandangan lain tentang faktor-faktor yang mempengaruhi etika kerja termasuk pula: 1). Volume upah kerja yang dapat memenuhi kebutuhan seseorang; 2). Suasana kerja yang menggairahkan atau iklim yang ditunjang dengan komunikasi demokrasi yang serasi dan manusiawi antara pimpinan dan bawahan; 3). Penanaman sikap dan pengertian dikalangan pekerja; 4). Sikap jujur dan dapat dipercaya dari kalangan pimpinan terwujud dalam kenyataan; 5). Penghargaan terhadap hasrat dan kebutuhan untuk maju atau penghargaan terhadap yang berprestasi; 6). Sarana yang menunjang bagi kesejahteraan mental dan fisik, seperti tempat olahraga, mesjid, rekreasi dan hiburan (Muhaimin, 2008).

Uraian di atas menggaris bawahi adanya faktor yang mempengaruhi etika kerja dapat berasal dari dalam diri karyawan maupun dari luar diri karyawan. Semua itu berpengaruh dalam membentuk beretika tidaknya seseorang dalam melaksanakan pekerjaan.

Etika kerja selalu mengacu pada pada nilai-nilai etis yang menghargai dan meningkatkan harkat dan martabat manusia itu. Dan apabila hal itu dapat dilaksanakan dalam praktik kehidupan sehari-hari, maka terciptalah etos kerja yang sehat atau sesuatu yang etis.

Seorang yang memiliki karakter etika kerja yang baik adalah jika seorang memiliki nilai-nilai: 1). Amanah; 2). Saling menghormati; 3). Bertanggung jawab; 4). Adil; 5). Penyayang; 6). kewarganegaraan (Rashid, Husin, \& Othman, 2006). Empat hal berikut ini juga merupakan nilai-nilai etika kerja, yaitu jika dalam bekerja: 1). Mengandung unsur utilitas atau manfaat; 2). Terdapat unsur hak dan kewajiban; 3). 
Mengandung keadilan dan kejujuran; 4). Mengandung rasa melindungi (Saifullah, 2011).

Pandangan lain menunjukkan bahawa nilai-nilai etika kerja yang seharusnya melekat pada setiap pekerjaan yang profesional memiliki ciri: 1). Keinginan untuk menjunjung tinggi mutu pekerjaan; 2). Menjaga harga diri di dalam melaksanakan pekerjaan; 3). Keinginan untuk memberikan layanan kepada masyarakat melalui karya profesionalnya (Muhaimin, 2004).

Pendapat-pendapat di atas menunjukkan cukup banyak nilai-nilai etika yang menjadi tolak ukur seseorang memiliki kerja yang beretika atau tidak. Dengan menerapkan nilai-nilai etika kerja seperti di atas maka seseorang dapat menjadi lebih baik perilakunya dalam bekerja, sekaligus dapat menjadi teladan bagi lingkungan organisasi perusahaan.

\section{Etika Kerja dalam Perspektif Islam}

Bagian ini penulis menyajikan konsep-konsep ilmiah mengenai etika kerja dalam perspektif Islam. Konsep-konsep yang di sajikan ialah tentang pengertian, peran penting, faktor-faktor, dan nilai-nilai etika kerja menurut perspektif Islam.

Islam menuntut setiap manusia bekerja, berusaha mencari rezeki bagi diri sendiri dan keluarga. Di samping itu Islam juga menyatakan bahwa sesuatu pekerjaan yang baik ialah tugas yang diamanahkan kepada seorang insan. Maka apabila seseorang itu menjalankan tugasnya ataupun bekerja, dengan sendirinya berarti insan tersebut sedang menunaikan amanah Allah.

Terminologi paling dekat pengertian etika dalam Islam adalah akhlak. Dalam Islam etika (akhlak) merupakan cerminan kepercayaan Islam (Iman). Etika Islam memberi sangsi internal yang kuat serta otoritas pelaksana dalam menjalankan standar etika (Nawatmi, 2010).

Dalam bisnis, etika dikenal dengan istilah etika bisnis, yaitu seperangkat prinsipprinsip etika yang membedakan yang baik dan yang buruk, harus, benar, salah dan lain sebagainya, dan prinsip-prinsip umum yang membedakan seseorang untuk mengaplikasikannya atas apa saja dalam dunia bisnis (Saifullah, 2011).

Secara khusus, etika yang dimaksud dalam penelitian ini ialah etika kerja. Etika kerja Islam merupakan cara pandang yang diyakini seorang Muslim bahwa bekerja itu bukan saja untuk memuliakan dirinya sebagai manusia, tetapi juga sebagai manifestasi dari amal soleh, dan oleh karenanya mempunyai nilai ibadah yang sangat luhur dihadapan Tuhan (Djakfar, 2012).

Berdasarkan pengertian-pengertian di atas, terlihat bahwa setiap individu yang bekerja, hendaklah sentiasa memiliki keyakinan dan kesadaran untuk berusaha untuk menunaikan tugas mereka menurut ajaran Islam. Hal tersebut karena ajaran Islam mementingkan bukan hanya nilai-nilai fisik dalam bekerja, tetapi juga nilai-nilai rohani seperti etika. Etika kerja dalam Islam tidak bersifat fisik, tetapi lebih menjurus kepada sikap-sikap dan tingkah laku yang ditunjukkan seorang Muslim dalam bekerja.

Bekerja menuntut adanya sikap baik budi, jujur dan amanah, kesesuaian upah serta tidak diperbolehkan menipu, merampas, mengabaikan sesuatu dan semena-mena, pekerjaan harus mempunyai komitmen terhadap agamanya, memiliki motivasi untuk menjalankan seperti bersungguh-sungguh dalam bekerja dan selalu memperbaiki muamalahnya. Itulah yang disebut dengan etika bekerja.

Dalam Islam etika kerja memiliki fungsi yang cukup penting. Setiap pekerja, terutama yang beragama Islam, harus dapat menemukan etika kerja secara Islami karena

Fakultas Ekonomi dan Bisnis - Universitas Malikussaleh 
pekerjaan yang ditekuninya bernilai Ibadah. Hasil yang diperoleh dari pekerjaannya juga dapat digunakan untuk kepentingan Ibadah, termasuk di dalamnya menghidupi ekonomi keluarga. Hasil yang diperoleh dari pekerjaannya juga dapat digunakan untuk kepentingan ibadah, termasuk di dalamnya menghidupi ekonomi keluarga. Oleh karena itu seleksi memilih pekerjaan dan menumbuhkan etos kerja yang Islami menjadi suatu keharusan bagi semua pekerja (Luth, 2001).

Etika kerja dalam Islam merupakan hal yang sangat penting dan mendasar karena etika kerja bagi umat Islam akan mampu mewujudkan apa yang diinginkannya sebagai bekal hidup di akhirat. Hal inilah yang mengakibatkan betapa mahal nilai etika sehingga Islam sangat menghargai orang-orang yang mempunyai karakter etos kerja yang tinggi sesuai dengan ajaran Islam. Dalam etos kerja Islami ada makna yang sangat krusial, yakni hikmah atas kehendak yang bisa melahirkan perubahan dalam kehidupan manusia dalam segala aspek nya, seperti sosial, ekonomi dan lain sebagainya (Djakfar, 2012).

Dalam bekerja sebagai salah satu upaya pemenuhan kebutuhan ekonomi, Islam memberikan pedoman etis sebagai berikut: 1). Bekerja adalah manifestasi keimanan; 2). Menghindari eksploitasi terhadap sumber-sumber alam dengan cara yang melampaui batas; 3). Menghindarkan dari perbuatan merugikan orang lain atau merusak lingkungan; 4). Rezeki yang didapatkan dari hasil kerja, sebagaiannya ada yang berfungsi sosial; 5). Adanya keterikatan individu terhadap diri dan kerja yang menjadi tanggung jawabnya; 6). Berusaha dengan cara halal dalam seluruh jenis pekerjaan; 7). Dilarang menjanjikan seseorang sebagai alat produksi atau binatang dalam kerja; 8). Islam tidak mengenal pekerjaan yang mendurhakai Allah seperti pemeras bahan-bahan minuman keras, pencatat riba, pelayan bar, dan bekerja dengan penguasa yang menyuruh kejahatan seperti membunuh orang; 9). Profesionalisme (Kholis, 2004).

Kesimpulan dari berbagi pendapat di atas, etika kerja Islam yang bersumber dari nilai-nilai Islam penting untuk pekerjaan karena pekerja yang bertika berarti mendedikasikan kerja sebagai kebajikan. Kebajikan terwujud dalam tingkah laku bekerja. Organisasi khususnya organisasi bisnis Islam yang mempunyai orang-orang yang senantiasa beretika atau berakhlak dalam bekerja mempengaruhi sikap dan tingkah lakunya dalam bekerja yang intinya adalah bekerja dengan sungguh-sungguh untuk mencapai prestasi dan tujuan perusahaan.

Faktor-faktor yang dapat mempengaruhi perilaku etis manusia adalah sebagai berikut: 1). Manusia itu sendiri, yakni adanya akal pikiran, hati, dan nafsu; 2). Lingkungan alam, lingkungan alam yang subur secara relatif dapat mempengaruhi manusia menjadi malas, sementara lingkungan yang miskin sumber daya alam dapat memacu manusia memiliki etos kerja yang tinggi; 3). Interpretasi hukum. Dalam masyarakat sekuler interprestasi hukum didasarkan pada nilai-nilai dan standar kontemporer yang selalu berubah-ubah, sementara dalam masyarakat Islam, nilai-nilai dan standar hukum dituntun ajaran Syariah dan kumpulan fatwa fikih (Djakfar, 2012)

Etika kerja dalam pendapat lain juga dipengaruhi oleh faktor pendalaman agama seseorang. Agama adalah sumber utama bagi penentuan baik buruk, benar salah dan adil curangnya perbuatan dan sikap laku seseorang. Dalam perkembangan hidup manusia terdapat faktor-faktor lain yang turut mempengaruhi nilai-nilai moral manusia, yaitu kondisi lingkungan sosial dan lingkungan alam dalam mana manusia tumbuh berkembang. Maka nilai moral yang mempengaruhi prilaku manusia ditentukan oleh hubungan manusia dengan Allah Yang Maha Kuasa, hubungan manusia dengan sesama 
manusia dalam lingkungan sosial dan hubungan manusia dengan berbagai komponen ekosistem dalam lingkungan alam (Salim, 2000).

Faktor-faktor yang dikatakan di atas menunjukkan bahwa etika kerja dipengaruhi oleh faktor manusia dan faktor bukan manusia. Tetapi pada intinya faktorfaktor tersebut mendorong seseorang untuk lebih beretika dalam bekerja, karena dalam pandangan Islam dengan beretika maka seseorang telah melaksanakan perintah-Nya dan menjauhi segala larangan-Nya serta didasari oleh keinginan untuk mengharap Ridha Allah SWT.

Etika kerja Islam meliputi prilaku atau tindakan seseorang yang menjurus kepada kebaikan seseorang. Untuk mengukur etika kerja baik atau benar, agar etika kerja memiliki beberapa nilai-nilai atau norma-norma. Etika kerja secara khusus tercermin dari sifat Rasulullah SAW sehingga menjadi pedoman dalam menegakkan etika kerja, yaitu: 1). kejujuran atau shiddiq; 2). keteguhan atau istiqomah; 3). kecerdasan atau fathanah; 4). dapat dipercaya atau amanah; dan 5). menyampaikan atau tabligh (Hafidhuddin, 2003).

Nilai-nilai etika kerja dalam pandangan Islam dapat juga dikembangkan dari berbagai aspek yang lebih beragam, seperti: 1). membangun budaya kerja yang bermoral positif untuk menyelamatkan asset perusahaan; 2). mempunyai kemauan yang sungguh-sungguh untuk menumbuh kembangkan aset perusahaan supaya dapat mendatangkan keuntungan yang lebih besar; 3). mengedepankan keteladanan dan disiplin kerja oleh pimpinan dan karyawan; 4) memberdayakan etos kerja yang jujur, amanah, dan bertanggung jawab atas tugas pekerjaan yang dibebankan kepadanya; 5). mempunyai moral yang terpuji dan tangguh dalam mengambil kebijakan yang menyangkut nasib perusahaan; 6). mampu berkomunikasi secara sehat antara sesama pekerja dan pimpinan-pimpinannya; 7). sopan santun terhadap lingkungan sekitar terutama sesama mitra kerja dan masyarakat secara luas; 8). bertakwa kepada Allah dengan menjalankan perintah dan menjauhi larangannya (Luth, 2001).

Nilai-nilai etika kerja dalam Islam juga memiliki ciri-ciri berikut ini: 1). kecanduan terhadap waktu; 2). memiliki moralitas yang bersih (ikhlas); 3). kecanduan disiplin; 4). konsekuen dan berani menghadapi tantangan; 5). memiliki sikap percaya diri; 6). orang yang kreatif; 7). tipe orang yang bertanggung jawab; 8). bahagia karena melayani; 9). memiliki harga diri; 10). memiliki jiwa kepemimpinan; 11). berorientasi ke masa depan; 12). hidup berhemat dan efisien; 13). keinginan untuk mandiri; 14). kecanduan belajar dan haus mencari ilmu; 15). tangguh dan pantang menyerah; 16). berorientasi pada produktivitas; 17) memperkaya jaringan silaturahim (Tasmara, 2004)

Berdasarkan nilai-nilai etika kerja di atas maka nilai-nilai etika kerja menjadi sangat mahal dan berarti sehingga Islam sangat menghargai orang-orang yang mempunyai karakter etos kerja yang tinggi sesuai dengan ajaran Islam. Dengan menegakkan etika kerja yang baik berarti seseorang melakukan amal yang baik dalam bekerja. Amal yang baik adalah sesuatu yang diperintahkan Allah SWT melalui Rasulullah SAW. Oleh karena itu, dalam Islam nilai-nilai yang baik bukan hanya khusus untuk kehidupan beragama, namun lebih kepada seluruh aspek kehidupan termasuk pula dalam bekerja.

\section{METODE PENELITIAN}

Penelitian ini merupakan penelitian yang menggunakan pendekatan campuran atau kombinasi (hybrid). Umumnya pendekatan ini digunakan karena peneliti merasa tidak puas dengan hasil penelitian kuantitatif yang tidak bersifat mendalam, sehingga

Fakultas Ekonomi dan Bisnis - Universitas Malikussaleh 
metode kualitatif juga digunakan sebagai pendamping penelitian kuantitatif (Herlanti, 2014).

Penelitian ini mempunyai tiga sumber data. Sumber data pertama ialah karyawan Bank Syariah di Kota Medan. Data-data yang berasal dari karyawan berguna untuk menganalisis tujuan penelitian yang pertama, yaitu pandangan karyawankaryawan tentang etika kerja Islam Bank Syariah di Kota Medan, khususnya karyawan di dua kantor cabang Bank Mandiri Syariah.

Sumber data kedua adalah data-data dari pimpinan. Data-data dari sumber ini bermanfaat menganalisis tujuan penelitian yang kedua, yakni pandangan para pimpinan tentang etika kerja Islam pada Bank Syariah di Kota Medan. Data-data tersebut diperoleh dari kedua pimpinan cabang Bank Syariah di Kota Medan seperti di atas.

Sumber data ketiga, Data-data penelitian juga bersumber dari referensi-referensi ilmiah. Kegunaannya adalah untuk menganalisis tujuan penelitian ketiga, yakni membangun rancangan model etika kerja Islam untuk institusi perbankan Syariah. Sumber-sumber referensi tersebut ialah Al-Quran, Hadits, dan pandangan ulama atau ilmuan Islam serta referensi relevan lainnya.

Penelitian ini menggunakan tiga teknik pengumpulan data. Pertama, angket, bermanfaat menganalisis tujuan penelitian yang pertama, yakni menganalisis pandangan karyawan-karyawan tentang etika kerja Islam pada Bank Syariah di Kota Medan. Kedua, wawancara. Teknik ini adalah untuk menganalisis tujuan kedua, yakni menganalisis pandangan para pimpinan Bank Syariah di Kota Medan tentang etika kerja di perusahaan mereka. Ketiga, menggali referensi ilmiah agar mampu menganalisis tujuan penelitian ketiga yakni membangun rancangan model etika kerja Islam untuk institusi perbankan Syariah. Berbagai referensi ilmiah tersebut ialah Al-Quran, Hadits, dan pandangan ulama atau ilmuan Islam serta referensi relevan lainnya.

Pengumpulan data dengan menyebarkan angket berupa daftar pertanyaan yang diberikan kepada responden dengan menggunakan skala Likert. Teknik analisis data dalam penelitian ini bermanfaat untuk menjawab rumusan masalah dan menganalisis tujuan penelitian. Teknik yang digunakan untuk menganalisis data ada dua, yakni analisis data kuantitatif dan analisis data kualitatif.

\section{PEMBAHASAN}

\section{Pandangan Karyawan-Karyawan Tentang Etika Kerja Islam pada Bank Syariah di Kota Medan}

Pandangan karyawan-karyawan tentang etika kerja Islam berdasarkan deskripsi data pada bagian sebelumnya. Dari jawaban-jawaban yang di isi responden, untuk seluruh nomor pertanyaan ada yang menjawab sangat setuju, setuju, dan netral yakni tentang mengatur waktu, disiplin, sikap percaya diri, bertanggung jawab, berbahagia, memiliki harga diri, berhemat, berorientasi produktivitas, silaturahim, kejujuran atau shiddiq, dapat dipercaya atau amanah, menyampaikan atau tabligh.

Sementara itu responden yang menjawab biasa saja/netral ialah pada pertanyaan tentang moralitas yang bersih, konsekuen dan berani menghadapi tantangan, kreatif, berjiwa kepemimpinan, berorientasi ke masa depan, keinginan mandiri, mencari ilmu, tangguh, keteguhan atau istiqamah, kecerdasan atau fathanah. Namun yang menjadi permasalahan yaitu pada jawaban mengenai mencari ilmu dan kecerdasan atau fathanah, terlihat jawaban responden agak lebih besar (12,8\%) dibanding jawaban biasa saja/netral yang lainnya. 
Dalam hal mencari ilmu, seharusnya para karyawan dalam mencari ilmu tidaklah harus setengah-setengah. Para karyawan harus lebih aktif lagi untuk mencari ilmu baik itu yang ada diperusahaan maupun yang ada di luar perusahaan, dari sesama teman di perusahaan pun karyawan dapat menggali ilmu lagi dari mereka yang lebih tinggi ilmu pengetahuan nya.

Di dalam kecerdasan atau fathanah, karyawan masih menganggap kecerdasan pada tiap karyawan sangat berbeda-beda padahal kecerdasan merupakan sifat Rasulullah SAW yang harus kita miliki, namun karyawan di perusahaan menganggap kecerdasan merupakan hal yang biasa atau netral. Seharusnya karyawan tersebut dapat menjadi cerdas yaitu dengan mencari ilmu dari karyawan-karyawan yang lainnya maupun bisa kita ambil ilmu tersebut dari pimpinan. Karena ilmu yang ingin kita cari tidak hanya kepada orang yang lebih tua saja tetapi bisa juga dengan belajar kepada orang yang memiliki ilmu yang tinggi walaupun usianya dibawah kita sekalipun sehingga nantinya para karyawan menganggap kecerdasan atau mencari ilmu menjadi sangat penting bagi pekerjaan mereka.

\section{Pandangan Para Pemimpinan Tentang Etika Kerja Islam pada Bank Syariah di Kota Medan}

Pandangan pimpinan tentang etika kerja Islam berdasarkan deskripsi data pada bagian sebelumnya, yaitu tentang hal-hal berikut ini: Apakah sumber/rujukan utama untuk melaksanakan etika kerja islam di perusahaan; Mengapa sumber Al- Qur'an tersebut digunakan; Manakah dari nilai-nilai etika kerja Islam yang di praktikkan di perusahaan; Apakah ada nilai-nilai lain yang digunakan diperusahaan selain nilai-nilai etika kerja Islam?; Apakah masalah-masalah yang dihadapi dalam melaksanakan proses etika kerja Islam di perusahaan; Faktor-faktor apa saja yang mendorong kesuksesan etika kerja Islam di perusahaan; Apakah strategi/cara/pola yang digunakan untuk menerapkan etika kerja Islam di perusahaan; Apakah hal-hal lain yang perlu disampaikan tentang etika kerja Islam.

Dari pertanyaan tentang sumber-sumber/rujukan utama untuk melaksanakan etika kerja Islam, pimpinan menjawab bahwa sumber utama tersebut adalah Al-Qur'an dan Hadits. Alasannya adalah karena Al-Quran dan Hadits merupakan pedoman hidup umat manusia. Yang harus dipraktikkan setiap umat manusia.

Di dalam Al-Qur'an terdapat ayat-ayat yang menjelaskan tentang fungsi AlQuran dan Hadits seperti analisis di bawah ini yang maksudnya: "Sungguh, kami telah mendatangkan sebuah kitab (Al-Qur'an) kepada mereka, yang Kami jelaskan atas dasar pengetahuan, sebagai petujuk dan rahmat bagi orang-orang yang beriman" (Al-Qur'an, Surah Al-Araf, $7: 52$ ).

Hal ini dapat terlihat bagi siapa saja (manusia) yang mengikuti petunjuk AlQur'an akan mendapatkan kemuliaan, kejayaan, keselamatan, dan kebahagiaan baik didunia maupun diakhirat. "Sungguh, kami telah mennrunkan sebuah kitab (Al-Qur'an) kepadamu (Muhammad) membawa kebenaran agar engkau dapat mengadili antara manusia dengan apa yang telah diajarkan Allah kepadamu, dan janganlah engkau menjadi penentang (orang yang tidak bersalah), karena (membela) orang0orang yang berkhianat" (Al-Qur'an, Surah An-Nisa, 4 : 105).

Sumber pokok ajaran Islam adalah Al-Qur'an sebab dari Al-Quran-lah diambil segala pokok syariat dan dalil-dalil syar'i yang mencakup seluruh aspek hukum bagi manusia dalam menjalani hidup didunia atau di akhirat. "Wahai manusia! Sungguh, telah datang kepadamu pelajaran (Al-Qur'an) dari Tuhanmu, penyembuh bagi penyakit

Fakultas Ekonomi dan Bisnis - Universitas Malikussaleh 
yang ada dalam dada, dan petunjuk serta rahmat bagi orang yang beriman" (Al-Qur'an, Surah Yunus, $10: 57)$.

Dari pertanyaan tentang manakah dari nilai-nilai etika kerja Islam yang di praktikkan di perusahaan, pimpinan menjawab bahwa yang dipraktikkan adalah nilainilai berikut ini: moralitas yang bersih, disiplin, sikap percaya diri, kreatif, bertanggung jawab, berjiwa kepemimpinan, berhemat, tangguh, silaturrahim, kejujuran atau shiddiq, keteguhan atau istiqamah, kecerdasan atau fathanah, dapat dipercaya atau amanah, menyampaikan atau tabligh. ETHIC, yang terdiri dari Excellence (kesempurnaan), Teamwork (kerjasama), Humanity (Kemanusiaan), Integrity (integritas), Customer focus (Fokus pada pelanggan).

Dari pertanyaan tentang masalah-masalah yang dihadapi dalam melaksanakan etika kerja Islam di perusahaan, pimpinan menjawab adalah adanya masalah-masalah sebagai berikut: Dari 2 pimpinan pada Bank Syariah di Kota Medan, masalah yang dihadapi dalam membangun dan melaksanakan etika kerja Islam di perusahaan yaitu: melayani nasabah agar nasabahnya puas dengan kinerja karyawan nya, bagaimana karyawan itu mempunyai sifat ETHIC yaitu : Excellence (Prudence; menjaga amanah dan melakukan perbaikan proses secara terus menerus; Competence; meningkatkan keahlian sesuai tugas yang diberikan dan tuntutan profesi banker); Teamwork (Trusted dan Trust; mengembangkan perilaku dapat dipercaya dan percaya, Contribution; memberikan kontribusi postif dan optimal); Humanity (Social dan Environment care; memiliki kepedulian yang tulus terhadap lingkungan dan sosial, Inclusivity; mengembangkan perilaku mengayomi); Integrity (Honesty; jujur, Good Governance; melaksanakan tata kelola yang baik); Customer focus (Innovation; mengembangkan proses, layanan, dan produk untuk melampaui harapan nasabah, Service Excellence; memberikan layanan terbaik yang melampaui harapan nasabah).

Dari pertanyaan tentang faktor-faktor apa saja yang mendorong kesuksesan proses kepemimpinan Islam di perusahaan. Pimpinan menjawab adalah karena faktor: Dengan gerakan Percaya diri (keyakinan); Antusias (energi positif); Semangat (komitmen).

Dari pertanyaan tentang strategi/cara/pola yang digunakan untuk membangun etika kerja Islam di perusahaan adalah dengan cara: - Pimpinan di Bank Syariah yang ada di Kota Medan cara yang digunakan untuk membangun kesuksesan menerapkan etika kerja Islam di perusahaan menjawab : mengadakan perjanjian secara berkala; efektivitas kelompok 1-5 orang adalah salah satu programmatic program; mengingatkan anggotanya untuk selalu berperilaku ETHIC; Memastikan bahwa anggotanya PAHAM akan informasi dari atasan; mendorong anggotanya untuk selalu lebih baik dari hari sebelumnya.

Hal terakhir, bahwa jawaban pimpinan tentang pertanyaan hal-hal lain yang perlu diperhatikan tentang etika kerja Islam adalah Etika (budaya) supaya terinsnalisasi dengan baik polanya itu harus dipaksa, terpaksa, jadi biasa dan menjadi budaya. Dibuat peraturan, dibuat reward, dan diberikan punishment.Yang melaksanakannya diberikan hadiah (reward), yang tidak melaksanakan diberikan hukuman (punishment).

\section{Model Etika Kerja Islam untuk Perbankan Syariah}

Model etika kerja Islam dalam bagian ini menganalisis dua hal, yaitu rumusan model etika kerja Islam untuk perbankan Syariah dan nilai-nilai etika kerja Islam untuk perbankan Syariah. 


\section{a. Rumusan Model Etika Kerja Islam untuk Perbankan Syariah}

Model etika Islam dalam penelitian ini dilihat dari tiga hal, yakni 1). Input: yakni faktor-faktor yang mempengaruhi etika kerja Islam; 2). Proses: yakni nilai-nilai yang diterapkan dalam pelaksanaan etika kerja Islam; dan 3) Output: Hasil atau dampak yang timbul dari pelaksanaan etika kerja Islam.

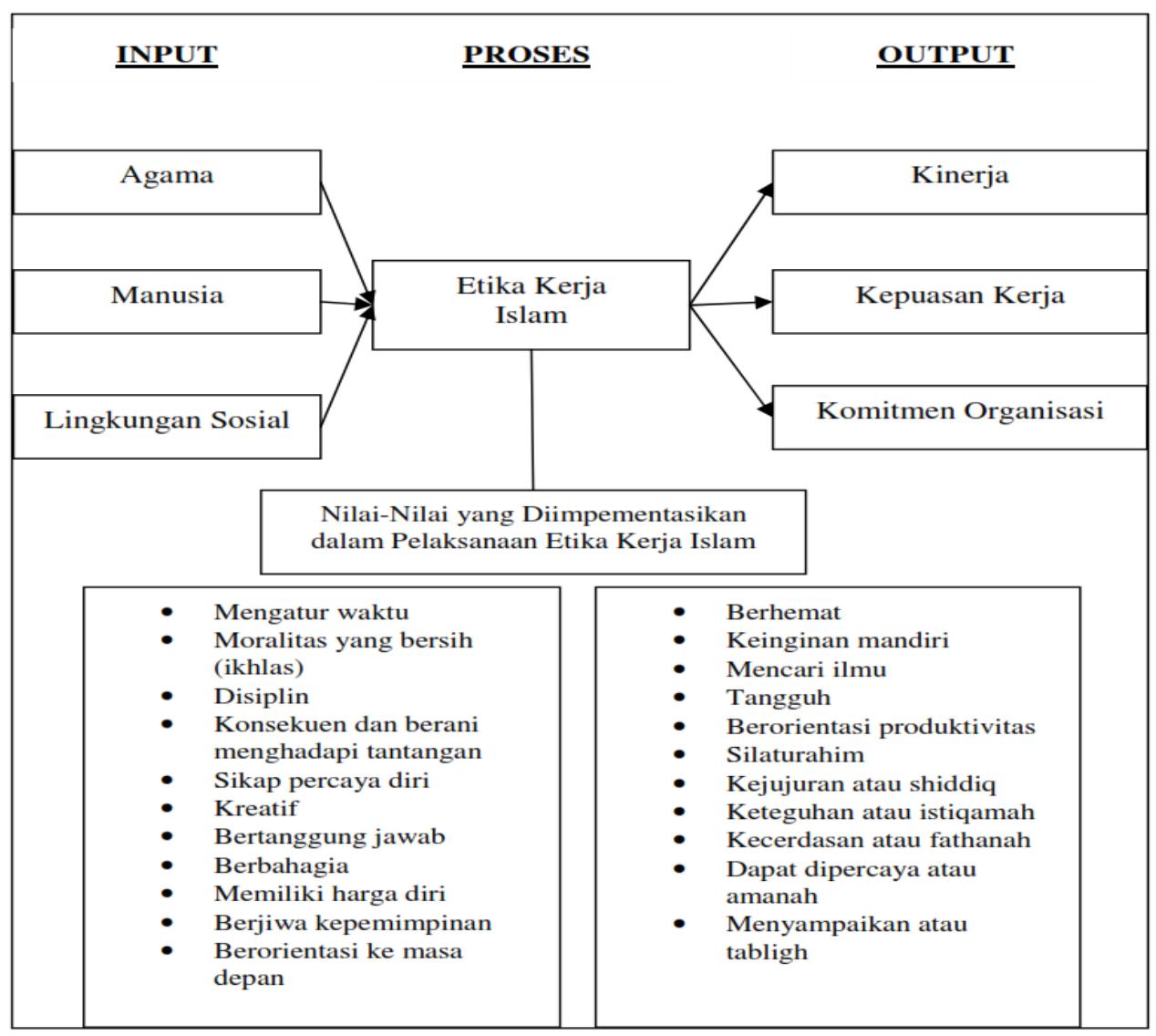

Gambar 1. Rumusan Model Etika Kerja Islam untuk Perbankan Syariah

\section{b. Elemen Input dalam Model Etika Kerja Islam di Perbankan Syariah}

Input di dalam penelitian ini merupakan faktor faktor yang mempengaruhi etika kerja Islam terdapat mengenai, agama; manusia; dan lingkungan sosial. Ketiga input atau faktor tersebut menentukan baik-buruknya etika kerja dalam pandangan Islam.

Input mengandung arti menerima masukan, memproses masukan, menyimpan perintahperintah pengolahan, dan menyediakan keluaran dalam bentuk informasi (Kuswayatno, 2006)

Input atau faktor-faktor yang mempengaruhi etika kerja Islam adalah faktorfaktor:

agama (Salim, 2000; Priharjo, 2006) manusia (Djakfar, 2012), lingkungan sosial (Djakfar, 2012, Priharjo, 2006).

Input pertama, agama. Agama adalah sumber utama bagi penentuan baik-buruk, benar-salah dan adil curangnya perbuatan dan sikap laku seseorang (Salim, 2000). Agama adalah seluruh ajaran dan hukum-hukumnya yang terdapat Di dalam Al-Qur'an 
yang diturunkan dari Allah, yang diwahyukan kepada Rasul-Nya, yaitu Nabi Muhammad SAW, untuk disampaikan dan didakwahkan kepada segenap umat manusia, sehingga manusia yang ada di muka bumi ini akan memperoleh kebahagiaan hakiki dan bermakna baik ketika hidup di dunia maupun di akhirat (Kurniawan, 2007). Dasar pengertian agama terdapat dalam Al-Qur'an yang maksudnya: "Sesungguhnya agama (yang diridai) di sisi Allah hanyalah Islam. Tiada berselisih orang-orang yang telah diberi Al Kitab kecuali sesudah dating pengetahuan kepada mereka, karena kedengkian (yang ada) di antara mereka. Barang siapa yang kafir terhadap ayat-ayat Allah maka sesungguhnya Allah sangat cepat hisab-Nya"(Al-Qur'an, Surah Al-Imran, 3 : 19).

Input kedua, manusia. Manusia merupakan satu kesatuan fisio-psikis yang ada Di dalam psikologi dikenal sebagai makhluk monodualis. Bahkan ada yang mengatakan satu kesatuan fisio-psikis rohani (Djakfar, 2012). Dasar pengertian manusia menurut perspektif Al-Qur'an yang maksudnya: "Dan di antara manusia (ada) orang yang mempergunakan perkataan yang tidak berguna untuk menyesatkan (manusia) dari jalan Allah tanpa pengetahuan dan menjadikan jalan Allah itu olok-olokan. Mereka itu akan memperoleh azab yang menghinakan" (Al-Qur'an, Surah Al-Luqman, 31 : 6).

Input ketiga, lingkungan sosial. Lingkungan sosial adalah kesatuan ruang dengan semua benda, daya, keadaan, dan makhluk hidup, termasuk manusia dan perilakunya, yang mempengaruhi kelangsungan perikehidupan dan kesejahteraan manusia serta makhluk hidup lain sosial (Djakfar, 2012).Allah berfirman dalam AlQur'an yang menggambarkan bagaimana lingkungan social yang maksudnya: "Hai manusia, sesungguhnya Kami menciptakan kamu dari seorang laki-laki dan seorang perempuan dan menjadikan kamu berbangsa-bangsa dan bersuku-suku supaya kamu saling kenal-mengenal. Sesungguhnya orang yang paling mulia diantara kamu disisi Allah ialah orang yang paling takwa diantara kamu. Sesungguhnya Allah Maha Mengetahui lagi Maha Mengenal”' (Al-Qur'an Surah Hujuraat, 49:13).

\section{c. Elemen Proses dalam Model Etika Kerja Islam}

Proses dalam penelitian ini dilihat dari nilai-nilai etika kerja yang dipraktikkan atau diimpelementasikan di perusahaan. Setiap pimpinan dan karyawan perusahaan wajib mengikuti dan melaksanakan nilai-nilai etika tersebut dalam proses bekerja setiap hari.

Proses mempunyai arti perubahan dalam perilaku sebagai hasil interaksi antara dirinya dengan lingkungannya dalam memenuhi kebutuhan hidupnya (Rasyidin, 2007). Proses dalam model etika kerja Islam bermakna mempraktikkan atau mengimplementasikan nilai-nilai etika kerja Islam yaitu: 1). mengatur waktu; 2). moralitas yang bersih (ikhlas); 3). disiplin; 4). konsekuen dan berani menghadapi tantangan; 5). sikap percaya diri; 6). kreatif; 7). bertanggung jawab; 8). berbahagia; 9). memiliki harga diri; 10). berjiwa kepemimpinan; 11). berorientasi ke masa depan; 12). berhemat; 13). keinginan mandiri; 14). mencari ilmu; 15). tangguh; 16). berorientasi produktivitas; 17) silaturahim (Disesuaikan dari nilai-nilai Tasmara, 2004). 1). kejujuran atau shiddiq; 2). keteguhan atau istiqomah; 3). kecerdasan atau fathanah; 4). dapat dipercaya atau amanah; dan 5). menyampaikan atau tabligh (Disesuaikan dari nilai-nilai Hafidhuddin, 2003). Penjelasan-penjelasan di bawah ini menggambarkan bagaimana nilai-nilai Etika Kerja Islam tersebut. 


\section{1) Mengatur waktu}

Mengatur waktu atau kecanduan terhadap waktu maksudnya, dia tidak mau ada waktu yang hilang dan terbuang tanpa makna. Jiwanya merintih bila ada satu detik berlalu tanpa makna. Baginya, waktu adalah rahmat yang tidak terhitung (Tasmara, 2004). Definisi mengatur waktu menurut perspektif Al-Qur'an yang maksudnya: "Demi masa; sesungguhnya manusia itu benar-benar dalam kerugian" (Al-Qur'an, Surah Al-Asr, $103: 1-2$ ).

\section{2) Moralitas yang bersih (ikhlas)}

Ikhlas merupakan pokok keimanan dan landasan utama agama. Ikhlas adalah salah satu rahasia amal shaleh. Al-Qur'an menjelaskan bahwa yang dimaksud dengan amal shaleh adalah yang melengkapi tiga perkara tersebut adalah ikhlas untuk mengharapkan ridha-Nya yang Maha Mulia (Haryadi, 2010). Definisi ikhlas menurut perspektif Al-Qur'an yang maksudnya: "Katakanlah: sesungguhnya sembahyangku, ibadatku, hidupku dan matiku hanyalah untuk Allah, Tuhan semesta alam, Tiada sekutu bagi-Nya; dan demikian itulah yang diperintahkan kepadaku dan aku adalah orang yang pertama-tama menyerahkan diri (kepada Allah)" (Al-Qur'an, Surah Al-An'am, 6 : 162163).

\section{3) Disiplin}

Pengertian disiplin di mana yang dimaksud adalah disiplin kerja. Tanpa memiliki kedisiplinan maka tidak bisa dibayangkan untuk tercapainya produktivitas. Disiplin jangan diartikan ketaatan kepada orang tua atau atasan saja tetapi juga mematuhi kebiasaan baik hukum dan sistem perusahaan (Ardhana, 2007). Definisi disiplin menurut perspektif Al-Qur'an yang maksudnya: "Hai orang-orang yang beriman, taatilah Allah dan taatilah Rasul (Nya), dan ulil amri di antarakamu. Kemudian jika kamu berlainan pendapat tentang sesuatu, maka kembalikanlah ia kepada Allah (AlQur'an) dan Rasul (sunnahnya), jika kamu benar-benar beriman kepada Allah dan hari kemudian. Yang demikian itu lebih utama (bagimu) dan lebih baik akibatnya" (AlQur'an, Surah An-Nisa, 4 : 59).

\section{4) Konsekuen dan berani menghadapi tantangan}

Setiap karyawan mempunyai kewajiban dan hak, yang timbul sebagai konsekuensinya dari adanya hubungan kerja, yaitu hubungan antara karyawan dan pengusaha atau perusahaan dalam hal pekerjaan. Kedua belah pihak telah mengadakan kesepakatan untuk mengadakan perjanjian, baik tertulis maupun lisan, baik sendirisendiri maupun bersama-sama mengenai pekerjaan (Mulianto, Cahyadi, \& Widjajakusuma, 2006). Definisi konsekuen menurut perspektif Al-Qur'an yang maksudnya: "Sesungguhnya yang sebenar-benar orang mukmin ialah orang-orang yang beriman kepada Allah danRasul-Nya dan apabila mereka berada bersama-sama Rasulullah dalam sesuatu urusan yang memerlukan pertemuan, mereka tidak meninggalkan (Rasulullah) sebelum meminta izin kepadanya. Sesungguhnya orangorang yang meminta izin kepadamu (Muhammad) mereka itulah orang-orang yang beriman kepada Allah dan rasul-Nya, maka apabila mereka meminta izin kepadamu karena sesuatu keperluan, berilah izin kepada siapa yang kamu kehendaki di antara mereka,dan mohonkanlah ampunan untuk mereka kepada Allah.Sesungguhnya Allah Maha Pengampun lagi MahaPenyayang.”(Al-Qur'an, Surah An-Nurs: 62).

\section{5) Sikap percaya diri}

Percaya diri adalah percaya akan adanya kemampuan-kemampuan dan saranasarana yang dilimpahkan oleh Allah kepada kita, maka itu merupakan suatu sikap percaya diri yang terpuji, dan patut bagi setiap orang untuk mendidik dirinya dengan 
sikap percaya diri seperti itu, agar ia menjadi seorang yang berkepribadian kuat (ALhilali, 2006). Percaya diri menurut perspektif Al-Qur'an yang maksudnya: "Janganlah kamu bersikap lemah, dan janganlah (pula) kamu bersedih hati, padahal kamulah orangorang yang paling tinggi (derajatnya), jika kamu orang-orang yang beriman”. (AlQur'an, Surah Al-Imran, $3: 139)$.

\section{6) Kreatif}

Kreatif didefinisikan sebagai suatu kemampuan yang dimiliki seseorang (sekelompok orang) yang memungkinkan mereka menemukan pendekatan-pendekatan atau terobosan baru dalam menghadapi situasi atau masalah tertentu yang biasanya tercermin dalam pemecahan masalah dengan cara yang baru atau unik yang berbeda dan lebih baik dari sebelumnya (Madjadikara, 2005). Kreatif menurut perspektif Al-Qur'an yang maksudnya: "Tidakkah mereka memperhatikan burung-burung yang dimudahkan terbang di angkasa bebas. Tidak ada yang menahannya selain daripada Allah. Sesungguhnya pada yang demikian itu benar-benar terdapat tanda-tanda (kebesaran Tuhan) bagi orang-orang yang beriman" (Al-Qur'an, Surah An-Nahl, $16: 78$ ).

\section{7) Bertanggung jawab}

Tanggung jawab adalah siap menerima kewajiban atau tugas. Setiap orang semestinya punya kewajiban untuk menjadi pribadi yang bertanggung jawab sepenuhnya terhadap setiap tindakan yang dilakukannya, karena setiap tindakan kita pasti membawa pengaruh positif atau negatif, pada lingkungan sekitar kehidupan kita (Wuryano, 2007).

Tanggung jawab menurut perspektif Al-Qur'an yang maksudnya: "Apakah manusia mengira, bahwa ia akan dibiarkan begitu saja (tanpa pertanggung jawaban)?" (Al-Qur'an, Surah Al-Qiyamah,75 : 36).

\section{8) Berbahagia}

Bahagia adalah suatu perasaan yang selalu timbul secara istimewa di dalam hati manusia. Kadang karena terasa nikmat dan menyenangkan, perasaan bahagia selalu terasa baru dan sulit didefinisikan. Dengan kata lain bahgia merupakan rasa yang sulit didefinisikan dengan kata-kata (Poerwopoespito, 2007). Berbahagia diri menurut perspektif Al-Qur'an yang maksudnya: "Apakah manusia mengira, bahwa ia akan dibiarkan begitu saja (tanpa pertanggung jawaban)?”. (Al-Qur'an, Surah Al-Qiyamah, 75: 36).

\section{9) Memiliki harga diri}

Harga diri merupakan penilaian menyeluruh mengenai diri sendiri, bagaimana dia menyukai pribadinya, harga diri mempengaruhi kreatifitasnya, dan bahkan apakah dia akan menjadi seorang pemimpin atau pengikut (Tasmara, 2009). Harga diri menurut perspektif Al-Qur'an yang maksudnya: "kekuatan itu hanyalah bagi Allah, bagi rasulNya dan bagi orang-orang munafik itu tiada mengetahui” (Al-Qur'an, Surah AlMunaafiqun, $63: 8$ ).

\section{0) Berjiwa kepemimpinan}

Kepemimpinan bararti kemampuan untuk mengambil posisi dan sekaligus memainkan peran sehingga kehadiran dirinya memberikan pengaruh pada lingkungan (Tasmara, 2004). Definisi berjiwa kepemimpinan menurut perspektif Al-Qur'an yang maksudnya: "Hai orang-orang yang beriman, janganlah kamu ambil menjadi teman kepercayaanmu orang-orang yang diluar kalanganmu (karena) mereka tidak hentinya (menimbulkan) kemudaratan bagimu. Mereka menyukai apa yang menyusahkan kamu. Telah nyata kebencian dari mulut mereka, dan apa yang disembunyikan oleh hati 
mereka lebih besar lagi. Sungguh telah kami terangkan kepadamu ayat-ayat (kami), jika kamu memahaminya”. (Al-Qur'an, Surah Al-Imran, 3: 118).

\section{1) Berorientasi ke masa depan}

Seorang yang berorientasi masa depan senantiasa melihat masa depan sebagai peluang dan tantangan serta senantiasa melakukan inovasi pelayanan dan teknologi. Sedangkan orang yang hanya terpaku pada apa yang dimiliki saat ini, tanpa mau berkreasi termasuk orang yang berorientasi masa kini, tanpa melihat masa depan. (Sudarma, 2008). Definisi berorientasi ke masa depan menurut perspektif Al-Qur'an yang maksudnya: "(Yaitu) bagi siapa diantaramu yang berkehendak akan maju atau mundur; tiap-tiap diri bertanggung jawab atas apa yang telah diperbuatnya" (Al-Qur'an, Surah Al-Muddaththir,74 : 37-38).

\section{2) Berhemat}

Hemat dan kerja adalah suatu sikap mental positif, namun untuk mau berhemat dan bekerja keras, kita harus mempunyai pengertian bahwa hemat dan bekerja keras harus dilakukan dalam keadaan apapun, baik saat krisis maupun saat tidak krisis (Poerwopoespoespito, 2007, hal 152). Definisi berhemat menurut perspektif Al-Qur'an yang maksudnya:"Dan berikanlah kepada keluarga-keluarga yang dekat akan haknya, kepada orang miskin dan orang yang dalam perjalanan; dan janganlah kamu menghambur-hamburkan (hartamu) secara boros; sesungguhnya pemboros-pemboros itu adalah sangat ingkar kepada Tuhannya" (Al-Qur'an, Surah Al-Isra, 17 : 26 27).

\section{3) Keinginan mandiri}

Seorang dikatakan mandiri apabila orang tersebut dapat melakukan keinginan dengan baik tanpa adanya ketergantungan pada pihak lain dalam mengambil keputusan atau bertindak, termasuk mencukupi kebutuhan hidupnya, tanpa adanya ketergantungan dengan pihak lain (Suharyadi, Nugroho, Purwanto, \& Faturrahman, 2007)

Definisi keinginan mandiri menurut perspektif Al-Qur'an yang maksudnya:"Hai orang-orang yang beriman, janganlah kamu melanggar syiar-syiar Allah, dan jangan melanggar kehormatan bulan-bulan haram, jangan (mengganggu) binatang-binatang had-ya, dan binatang-binatang qalaa-id, dan jangan (pula) mengganggu orang-orang yang mengunjungi baitullah sedang mereka mencari karunia dan keridhaan dari Tuhannya dan apabila kamu telah menyelesaikan ibadah haji, maka bolehlah berburu. Dan janganlah kebencian mu kepada sesuatu kaum karena mereka menghalang-halangi kamu dari Masjidil Haram, mendorongmu berbuat aniaya (kepada mereka). Dan tolong menolong lah kamu dalam berbuat dosa dan pelanggaran. Dan bertakwalah kamu kepada Allah, sesungguhnya Allah amat berat siksa-Nya" (Al-Qur'an, Surah AlMaidah, $5: 2$ ).

\section{4) Mencari ilmu}

Tujuan hidup yang benar adalah pengabdian kepada Allah, dan semata-mata untuk Allah. Kesejahteraan didunia bukanlah target. Ia hanyalah pengikut dari pengabdian itu. Mencari ilmu pun harus dilandasi dengan tujuan seperti itu. Bahkan, ukuran kemajuan ilmu itu sendiri harus di ukur dengan progresi pencapaian tujuan tadi (Shahab, 2007). Definisi mencari ilmu menurut perspektif Al-Qur'an yang maksudnya: "Dan janganlah kamu mengikuti apa yang kamu tidak mempunyai pengetahuan tentangnya. Sesungguhnya pendengaran, penglihatan dan hati, semuanya itu akan diminta pertanggung jawabannya". (Al-Qur'an, Surah Al-Isra, 17 : 36).

\section{5) Tangguh}

Berlandaskan sistem nilai dan moral yang tinggi, sikap tangguh dalam mengatasi kesulitan dan rintangan yang dialaminya pada pelaksanaan tugas-tugas perkembangan

Fakultas Ekonomi dan Bisnis - Universitas Malikussaleh 
sebelum memasuki masa depan (Gunarsa, 2008). Definisi tangguh menurut perspektif Al-Qur'an yang maksudnya: "Kemudian kami selamatkan dia dan pengikutpengikutnya kecuali istrinya; dia termasuk orang yang tertinggal (dibinasakan)" (AlQur'an, Surah Al-Araf, $7: 83$ )

\section{6) Berorientasi produktivitas}

Produktivitas kerja adalah kemampuan kemampuan untuk menghasilkan sejumlah barang dan jasa dengan kualitas tertentu dalam satuan tertentu yang telah ditetapkan, selain itu pula produktivitas mengandung pengertian yang berkenaan dengan konsep ekonomis, filosofis dan sistem (Tasmara, 2004). Definisi berorientasi produktivitas menurut perspektif Al-Qur'an yang maksudnya:“Dan katakanlah, Bekerjalah kamu, maka Allah dan Rasul nya, serta orang-orang yang beriman akan melihat pekerjaan mu itu, dan kamu akan dikembalikan kepada Allah Yang Maha Mengetahui yang ghaib dan yang nyata, lalu Allah memberitakan kepadamu apa yang telah kamu kerjakan"(Al-Quran, Surah At-Taubah, 9 : 105).

\section{7) Silaturahim}

Salah satu pintu keberkahan hidup adalah gemar menyambang silaturahim. Silaturahim terdiri dari dua kata, yaitu shilat, yang berarti hubungan, menyambung, dan rahim, yang berarti kasih sayang. Jadi, silaturahim adalah menyambung hubungan kasih sayang (el-Bantanie, 2010).

Definisi silaturahim menurut perspektif Al-Qur'an yang maksudnya: "Hai sekalian manusia, bertakwalah kepada Tuhan-mu yang telah menciptakan kamu dari diri yang satu, dan dari padanya Allah menciptakan istrinya, dan daripada keduanya Allah memperkembangbiakkan laki-laki dan perempuan yang banyak. Dan bertakwalah kepada Allah dengan mempergunakan nama-Nya, kamu saling meminta satu sama lain, dan peliharalah hubungan silaturahim. Sesungguhnya Allah selalu menjaga dan megawasi kamu"(Al-Quran, Surah An-Nisa, $4: 1$ ).

\section{8) Kejujuran atau shiddiq}

Kejujuran mengandung enam makna, yaitu: kejujuran dalam berbicara, kejujuran dalam niat dan kemauan, kejujuran dalam tindakan, kejujuran dalam rencana, kejujuran dalam merealisasikan semua ketentuan agama. Bila orang sudah mempunyai semua sifat tersebut, ia disebut sebagai Siddiq, kata sifat yang intensif (mubalaghah) untuk siddiq (Rakhmat, 2006). Definisi kejujuran atau shiddiq menurut perspektif AlQur'an yang maksudnya: "Hai orang-orang yang beriman, bertaqwalah kepada Allah, dan hendaklah kamu bersama orang-orang yang benar" (Al-Quran, Surah At-Taubah, 9 :119)

\section{9) Keteguhan atau istiqamah}

Istiqamah artinya konsisten dalam iman dan nilai-nilai yang baik, meskipun mengahadapi berbagai godaan dan tantangan.istiqamah dalam kebaikan ditampilkan dengan keteguhan, kesabaran, serta keuletan sehingga menghasilkan sesuatu yang optimal. Istiqamah merupakan hasil dari suatu proses yang dilakukan secara terusmenerus (Amrin, 2005).

Definisi istiqamah menurut perspektif Al-Quran yang maksudnya: "Sesungguhnya orang-orang yang mengatakan: "Tuhan kami ialah Allah" kemudian mereka meneguhkan pendirian mereka, maka malaikat akan turun kepada mereka dengan mengatakan: "Janganlah kamu takut dan janganlah merasa sedih; dan gembirakanlah mereka dengan jannah yang telah dijanjikan Allah kepadamu". Kamilah pelindung-pelindungmu dalam kehidupan dunia dan akhirat; di dalamnya kamu 
memperoleh apa yang kamu inginkan dan memperoleh (pula) di dalamnya apa yang kamu minta" (Al-Quran, Surah Fussilat, 41 : 30-31).

\section{0) Kecerdasan atau fathanah}

Fathanah artinya mengerti, memahami, dan mengahayati secara mendalam segala hal yang terjadi dalam tugas dan kewajiban. Sifat ini akan menumbuhkan kreativitas dan kemampuan untuk melakukan berbagai macam inovasi yang bermanfaat (Amrin, 2005). Sifat fathnah sebagaimana terdapat dalam firman Allah SWT yang maksudnya: "Berkata Yusuf, jadikanlah aku bendaharawan negara (Mesir). Sesungguhnya aku adalah orang yang pandai menjaga lagi berpengetahuan". (AlQuran, Surah Yusuf, 12:55).

\section{1) Dapat dipercaya atau amanah}

Amanah tersebut melengkapi segala yang dipertaruhkan kepada umatnya, Yakni amanah harus dipelihara, dilaksanakan serta dilayani. Amanah dalam pandangan islam cukup luas pengertiannya. Melambangkan arti bermacam-macam, akan tetapi semuanya bergantung kepada perasaan manusia yang dipercayakan amanah kepadanya (Albantany, 2014).

Definisi amanah menurut perspektif Al-Quran yang maksudnya: "Sesungguhnya Allah menyuruh kamu menyampaikan amanah kepada yang berhak menerimanya, dan (menyuruh kamu) apabila menetapkan hukum diantara manusia supaya kamu menetapkan dengan adil. Sesungguhnya Allah memberi pengajaran yang sebaik-baiknya kepadamu. Sesungguhnya Allah Maha Mendengar lagi Maha Melihat" (Al-Quran, Surah An-Nisa, 4 : 58).

\section{2) Menyampaikan atau tabligh}

Tabligh berarti menyampaikan ajaran Allah kepada manusia dengan ungkapan yang menyentu hati dan nasihat yang bijaksana. Karena itu pesan agama yang sifatnya caci maki, provokasi, atau humor yang memancing tawa bukanlah tabligh (Musa, 2014, hal 227).

Definisi tabligh menurut perspektif Al-Quran yang maksudnya:

"Sesungguhnya Allah menyuruh kamu menyampaikan amanat kepada yang berhak menerimanya, dan (menyuruhmu) apabila menetapkan hukum di antara manusia supaya kamu menetapkan dengan adil. Sesungguhnya Allah memberi pengajaran yang sebaik-baiknya kepadamu. Sesungguhnya Allah adalah maha mendengar lagi maha melihat"(Al-Qur'an, Surah An-Nisa, 4:58).

\section{d. Elemen Output dalam Model Etika Kerja Islam}

Ouput yang dimaksud dalam model penelitian ini adalah dampak atau akibat yang timbul dengan adanya pelaksanaan etika kerja Islam. Output mengandung arti keluaran atau hasil pengolahan dari input yang diterima (Frans, 2002). Output atau hasil yang dapat dicapai dengan melaksanakan etika kerja Islam adalah kinerja, kepuasan kerja, dan komitmen organisasi. Beberapa penjelasan mengenai ketiga output tersebut dapat dirujuk dari teori dan penelitian-penelitian terdahulu seperti di bawah ini.

Pandangan Islam tentang kinerja yang maksudnya:"Dan dirikanlah salat dan tunaikanlah zakat. Dan kebaikan apa saja yang kamu usahakan bagi dirimu, tentu kamu akan mendapat pahalanya pada sisi Allah. Sesungguhnya Allah Maha Melihat apa-apa yang kamu kerjakan"(Al-Qur'an, Surah Al-Baqarah, 2 : 110).

Pandangan Islam tentang kepuasan kerja dapat dilihat dalam bagian di bawah ini yang maksudnya:"Kamu tak akan mendapati kaum yang beriman pada Allah dan hari akhirat, saling berkasih-sayang dengan orang-orang yang menentang Allah dan 
Rasul-Nya, sekalipun orang-orang itu bapak-bapak, atau anak-anak atau saudarasaudara ataupun keluarga mereka. Mereka itulah orang-orang yang telah menanamkan keimanan dalam hati mereka dan menguatkan mereka dengan pertolongan yang datang daripada-Nya. Dan dimasukan-Nya mereka ke dalam surga yang mengalir di bawahnya sungai-sungai, mereka kekal di dalamnya. Allah ridha terhadap mereka, dan merekapun merasa puas terhadap (limpahan rahmat)-Nya. Mereka itulah golongan Allah. Ketahuilah, bahwa sesungguhnya hizbullah itu adalah golongan yang beruntung"(AlQur'an, Surah Al-Mujadilah, 58 : 22). Pandangan Islam tentang komitmen organisasi seperti penjelasan yang maksdunya:

"Bahwasanya orang-orang yang berjanji setia kepada kamu sesungguhnya mereka berjanji setia kepada Allah. Tangan Allah di atas tangan mereka, maka barangsiapa yang melanggar janjinya niscaya akibat ia melanggar janji itu akan menimpa dirinya sendiri dan barangsiapa menepati janjinya kepada Allah maka Allah akan memberinya pahala yang besar" (Al-Qur'an, Surah Al-Fath, $48: 10$ )

Selanjutnya dilihat pula bagaimana keterkaitan etika kerja dengan kinerja, kepuasan kerja, dan komitmen organisasi menurut teori dan penelitian berikut ini.

Pertama, keterkaitan etika kerja Islam dengan kinerja. Hasil penelitian menunjukkan adanya pengaruh secara langsung antara variabel etos kerja Islami terhadap kinerja karyawan, maka semakin baik etos kerja Islami yang dimiliki oleh karyawan mengakibatkan semakin meningkatkan pula kinerja karyawan. Ada faktorfaktor yang mempengaruhi terjadinya pengaruh signifikan pada etos kerja Islamiterhadap kinerja karyawan tersebut, disebabakan karena berdasarkan data-data yang diperoleh dilapangan diketahui bahwa karyawan selama ini bekerja berorientasi tingkat pemahaman spiritual sehingga didalam pengelolaan sumber daya manusia lebih menekankan pemahaman etos kerja Islami yang didasarkan pada Al-Quran dan Hadist agar produktivitas kerja karyawan dapat menunjang kepuasan pelanggan, serta mempengaruhi kinerja yang ditunjukkan oleh karyawan (Indica, 2013)

Kedua, keterkaitan etika kerja Islam dengan kepuasan kerja. etika kerja Islam lebih memberi penekanan kepada aspek sosial yang lebih baik di tempat kerja berbanding etika kerja protestan. Beliau mendapati etika kerja Islam mengutamakan nilai-nilai murni seperti memelihara kehormatan manusia, mementingkan ketaatan dan ketekunan bekerja. Etika kerja Islam juga melibatkan aktiviti pekerjaan secara bekerjasama dan bermusyawarah dalam menghadapi sebarang rintangan dan masalah. Kerja secara bersungguh-sungguh dilihat sebagai nilai murni dan mereka yang komited terhadap pekerjaan akan lebih berjaya dalam kehidupan (Ali, 2008).

Ketiga, keterkaitan etika kerja Islam dengan komitmen organisasi. berkaitan dengan etika kerja Islam, dalam kehidupan berorganisasisetiap muslim dituntut untuk berkomitmen terhadaporganisasi di dunia dengan satu tuntutan bahwa segala bentuk pertumbuhan dan dan perkembangan materil harus ditunjukkan demi keadilan, kebenaran dan peningkatan ketakwaan spiritual baik bagi organisasi maupun dirinya sendiri sebagai wujud pertanggungjawaban sebagai khalifah dibumi. Semakin tinggi etika kerja Islam didalam organisasi maka akan semakin tinggi komitmen yang dimiliki organisasi (Jamil, 2007).

Dengan demikian hal ini sejalan dalam penelitian (Indica, 2013) dalam judul "Pengaruh Etos Kerja Islami Dan Gaya Kepemimpinan Transformasional Terhadap Komitmen Organisional Dan Kinerja Karyawan (studi Pada Waroeng Stike And Shake Di Kota Malang)". Jadi, dari jurnal ini, etos kerja islami, gaya kepemimpinan transformasional, komitmen, dan kinerja karyawan sangat berpengaruh besar antara satu

Fakultas Ekonomi dan Bisnis - Universitas Malikussaleh 
dengan yang lainnya. Jadi, dari hasil jurnal ini menunjukkan: 1). Etos kerja Islami berpengaruh positif dan signifikan terhadap komitmen organisasional; 2). Gaya kepemimpinan transformasional berpengaruh positif dan signifikan terhadap komitmen organisasional; (3) etos kerja islami berpengaruh positif dan signifikan terhadap kinerja karyawan; (4) gaya kepemimpinan transformasional berpengaruh positif dan signifikan terhadap kinerja karyawan; (5) komitmen organisasional berpengaruh positif dan signifikan terhadap kinerja karyawan; (6) komitmen organisasi memediasi pengaruh etos kerja islami terhadap kinerja karyawan; (7) komitmen organisasi memediasi pengaruh gaya kepemimpinan transformasional terhadap kinerja karyawan.

Selain itu, penelitian (Ali, 2009) dalam judul "Pengaruh Kepemimpinan dan Etos Kerja Islami Terhadap Kinerja Karyawan Di Koperasi Jasa Keuangan Syariah Baitul Maal Wat Tamwil Di Kecamatan Rembang”. Bahwa judul dari penelitian ini yaitu variabel kepemimpinan dan etos kerja secara simultan mempunyai pengaruh yang signifikan terhadap kinerja karyawan pada KJKS BMT di Kecamatan Rembang. Pada variabel etos kerja secara parsial tidak mempunyai pengaruh yang signifikan terhadap kinerja karyawan, saran yang diharapkan akan bermanfaat bagi KJKS BMT di kecamatan Rembang berkaitan dengan pengaruh kepemimpinan, etos kerja Islami terhadap kinerja karyawan.

Dari penelitian (Husein, 2008) dalam judul "Keterkaitan Faktor-faktor organisasional, individual, konflik peran, perilaku etis dan kepuasan kerja akuntan manajemen". Dalam hasil penelitian ini, dari model yang diajukan indikator fit dari suatu model memang relatif kurang memuaskan, namun penelitian ini berhasil mengungkapkan faktor-faktor yang mempengaruhi konflik peran dan perilaku etis akuntan manajemen dan kepuasan kerja. Pemahaman kode etik, komitmen organisasional dan model peran mempengaruhi perilaku etis akuntan manajemen. Sedangkan prinsip moral tidak mempengaruhi perilaku etis akuntan manajemen. Sedangkan pemahaman kode etik, prinsip moral tidak mempengaruhi secara signifikan konflik peran. Faktor-faktor komitmen organisasional dan model peran yang justru mempengaruhi konflik peran. Sedangkan perilaku etis mempengaruhi kepuasan kerja sedangkan konflik peran tidak mempengaruhi kepuasan kerja akuntan manajemen.

Penelitian-penelitian di atas memperlihatkan bahwa etika kerja mempengaruhi kinerja, kepuasan kerja dan komitmen organisasi. Demikian juga dalam perbankan Syariah, etika kerja berdasarkan nilai-nilai Islam mempengaruhi kinerja, kepuasan kerja dan komitmen organisasi. Semakin baik etika kerja berdasarkan nilai-nilai Islam diimplementasikan di bank maka kinerja, kepuasan kerja dan komitmen organisasi akan semakin baik atau meningkat.

\section{PENUTUP}

Kesimpulan penelitian ini merupakan jawaban dari rumusan masalah dan tujuan penelitian yang telah dikemukakan pada bagian awal penelitian.

Pertama, Pandangan karyawan-karyawan tentang etika kerja Islam pada Bank Syariah di Kota Medan. Karyawan beranggapan bahwa etika kerja Islam pada Bank Syariah di Kota Medan dianggap cukup baik, karena nilai-nilai etika kerja Islam tersebut semua digunakan untuk melaksanakan perintah Allah SWT. Seluruh nilai-nilai tersebut harus dipatuhi oleh para karyawan agar dapat dicontoh dengan baik dari para pimpinan.

Kedua, Pandangan para pimpinan tentang etika kerja Islam pada Bank Syariah di Kota Medan. Bahwa menjadi seorang pemimpin harus berdasarkan Al-Qur'an dan 
Hadits. Oleh sebab itu dalam menjalankan etika kerja Islam di organisasi atau perusahaan harus dengan kesiapan yang matang dan memahami sifat-sifat Rasulullah SAW agar menjadi pimpinan yang beretika islam serta menjalani kepemimpinan sesuai dengan pedoman dan tata cara Islam dan mendapatkan keuntungan dengan halal yang diberkahi oleh Allah SWT agar menciptakan organisasi yang bergerak untuk mencapai suatu tujuan atas izin dan Ridha Allah SWT.

Ketiga, model etika kerja Islam. Model etika kerja Islam untuk perbankan Syariah yang dirumuskan ialah input (agama, manusia, lingkungan sosial), proses (mengamalkan nilai-nilai yakni mengatur waktu, moralitas yang bersih (ikhlas), disiplin, konsekuen dan berani menghadapi tantangan, sikap percaya diri, kreatif, bertanggung jawab, berbahagia, memiliki harga diri, berjiwa kpemimpinan, berorientasi ke masa depan, berhemat, keinginan mandiri, mencari ilmu, tangguh, berorientasi produktivitas, silaturahim, kejujuran atau shiddiq, kecerdasan atau fathanah, dapat dipercaya atau amanah, menyampaikan atau tabligh). Dan output (kinerja, kepuasan kerja, dan komitmen).

\section{DAFTAR PUSTAKA}

Albantany, N. (2014). dosa besar kecil yang terabaikan penyebab siksa azab kubur yang pedih. Jakarta: Kunci Iman.

AL-hilali, M. (2006). Adakah berhala pada diri kita. Jakarta: Gema Insani Press.

Ali, M. F. (2008, Juni 1). Hubungan Antara Stress Peranan, Ganjaran, Etika Kerja Dan Kepuasan Kerja. Jurnal Pengurusan Awam , 146.

Al-Qur'an. (2015). Al-Qur'an virtual. Retrieved Desember 28, 2015, from Universitas Muhammadiyah Malang: http://quran.umm.ac.id/id/

Al-Talib, H. (1992). Training guide for Islamic workers. Herndon VA: The International Institute of Islamic Thought.

Amrin, A. (2005). Strategi pemasaran asuransi Syariah. Jakarta: Grasindo.

Ardhana, K. (2007). Komunika Majalah Ilmiah Komunikasi dalam Pembangunan. Jakarta: Lipi.

Astarani, K. (2012). Hubungan kecerdasan emosional dengan etos kerja perawat magang di Rumah Sakit Baptis Kediri. Jurnal Penelitian Stikes Kediri , 4 (1), 17-23.

Asy'arie, M. (2005). Etos kerja Islam sebagai landasan pengembangan jiwa kewirausahaan. Dalam M. A. Aziz, R. Suhartini, \& A. Halim, Dakwah pemberdayaan masyarakat: Paradigma aksi metodologi. Yogyakarta: Pustaka Pesantren.

Bahri, S., \& Zamzam, F. (2014). Model penelitian kuantitatif berbasis SEM-Amos. Yogyakarta: Deepublish.

Brownlee, M. (2006). Pengambilan Keputusan Etis dan faktor-faktor didalamnya. Jakarta: PT. BPK Gunung Mulia.

Dewi, S. S., \& Bawono, I. R. (2008). Analisis pengaruh etika kerja Islam terhadap sikap karyawan bagian akuntansi dalam perubahan organisasi: Studi kasus pada Bank Umum non Syariah di wilayah eks Keresidenan Banyumas Jawa Tengah. Jurnal Akuntansi dan Auditing Indonesia-JAAI , 65-78. 
Djakfar, M. (2012). Etika bisnis. Jakarta: Penebar Plus .

el-Bantanie, M. S. (2010). Shalat Tarik Jodoh. Jakarta: PT. Elex Media Komputindo.

Fitria, A. (2003). Pengaruh Etika Kerja Islam Terhadap Sikap Akuntan dalam Perubahan Organisasi dengan Komitmen Organisasi Sebagai Variabel. Jurnal Maksi , 3 (1), 19.

Fitria, A. (2003). Pengaruh etika kerja Islam terhadap sikap akuntan dalam perubahan organisasi dengan komitmen organisasi sebagai variabel intervening. Jurnal Maksi , 3 (1), 14-35.

Frans. (2002). Membuat WEB dinamis dan Interaktif dengan CGI. Yogyakarta: ANDI yogyakarta.

hafidhuddin, D. (2003). Islam Aplikatif. Jakarta: Gema Insani Press.

Hanefa, A. (2003). Motivasi mematahkan Belenggu. Jakarta: PT. GramediaPustaka Utama.

Harega, A. (2004). Membangkitkan etos profesionalisme. Jakarta: PT. Gramedia Pustaka Utama.

Husaini, A. (2005). Wajah peradaban Barat: Dari hegemoni Kristen ke dominasi sekularliberal. Jakarta: Gema Insani Press.

Husein, M. F. (2008). Keterkaitan Faktor-faktor Organisasional, inividual, konflik peran, perilaku etis dan kepuasan kerja akuntan manajemen. Jurnal Manajemen Teori dan Terapan , 1 (1), 31-55.

Husni, I. (2014). Hubungan etos kerja dengan kinerja guru di SMK Negeri 1 Lubuk Sikaping. Bahana Manajemen Pendidikan , 2 (1), 341-346.

Indica, I. W. (2013). Pengaruh Etos Kerja Islami dan Dan Gaya Kepemimpinan Transformasional Terhadap Komitmen Organisasional Dan Kinerja Karyawan. Studi pada Waroeng Stike And Shake Di Kota Malang, 1-22.

Jamil, A. (2007). Pengaruh Etika Kerja Islam Terhadap Sikap-Sikap Pada Perubahan Organisasi Komitmen Organisasoi Sebagai Mediator. 31.

Juliandi, A., Irfan, \& Manurung, s. (2015). Metodologi penelitian bisnis: Konsep dan aplikasi. Medan: Umsu Press.

Kholis, N. (2004). Etika kerja dalam erspektif Islam. Al-Mawarid Journal of Islamic Law , 11 (1), 142-157.

Kurniawan, B. (2007). Pendidikan Agama Islam Untuk Perguruan Tinggi. Jakarta: Grafindo.

Kuswayatno, L. (2006). Mahir Berkomputer. Jakarta: Grafindo Media Pratama.

Lasahido, I., Nurazi, M. R., \& Nasution. (2014). Pengaruh motivasi dan etos kerja terhadap kinerja pegawai Sekretariat Dewan Perwakilan Rakyat Daerah (DPRD Provinsi Bengkulu. The Manager Review , 15 (7), 893-922.

Luth, T. (2001). Antara perut dan etos kerja dalam perspektif Islam. Kuala Lumpur: Utusan Publication and Distributor.

Madjadikara, A. S. (2005). Bagaimana Biro Iklan Memproduksi Iklan. Jakarta: PT. Gramedia Pustaka Umum. 
Mulianto, S., Cahyadi, E. R., \& Widjajakusuma, M. K. (2006). Panduan Lengkap Supervisi Diperkaya Perspektif Syariah. Jakarta: PT Elex Media Komputindo.

Musa, A. M. (2014). Membumikan Islam Nusantara. Jakarta: PT. Serambi Ilmu Semesta.

Nain, A. S., \& Yusoff, R. M. (2003). Konsep, Teori, dimensi dan isu pembangunan. Malaysia: University Teknologi Malaysia.

Poerwopoespito, F. S. (2007). Menggungah Mentalitas Profesional dan Pengusaha Indonesia. Bandung: Grafindo.

Poniman, F., Nugroho, I., \& Azzaini, J. (2006). Kubik Leadership. Jakarta: PT. Mizan Publika.

Priharjo, R. (2006). Pengantar Etika keperawatan. Yogyakarta: Penerbit Kanisius.

Purwanto, I. A. (2015). Kepemimpinan kiai dalam membentuk etos kerja santri: Studi kasus di badan usaha milik pesantren an-Nawawi Berjan Gebang Purworejo Jawa Tengah. Disertasi Doktor UIN Sunan Kalijaga Yogyakarta.

Qardhawi, Y. (2006). Ikhlas Sumber Kekuatan Islam. Jakarta: Gema Insani Press.

Qomar, M. (2007). Epistemologi pendidikan Islam: Dari metode rasional hingga metode kritik. Jakarta: Erlangga.

Rashid, A. R., Husin, S., \& Othman, A. J. (2006). Hala tuju pengurusan: Sumber manusia dan kerjaya. Kuala Lumpur: Utusan Publications.

Rusyan, A. T. (1989). Pendekatan dalam proses belajar mengajar. Bandung: Remaja Rosdakarya.

Saifullah, M. (2011). Etika bisnis Islami dalam praktek bisnis Rasulullah. Walisongo , 19 (1), 131.

Salim, E. (2000). Kembali ke jalan lurus. Jakarta: AlvaBet.

Shahih Bukhari. (2015). Ensiklopedi online Hadits 9 Imam. Dipetik Desember 28, 2015, dari Lidwa Pusaka: http://app.lidwa.com

Soekarso, \& Putong, I. (2015). Kepemimpinan. Yogyakarta: PT.Erlangga.

Sutono, \& Budiman, F. A. (2009). Analisis Manajemen. Pengaruh Kepemimpinan dan etos kerja Islami terhadap kinerja karyawan di koperasi jasa keuangan Syariah Biatul Maal wat Tamwil di Kemacatan Rembang , 4.

Tasmara, T. (2004). Membudayakan etos kerja Islami. Jakarta: Gema Insani Press.

Triyanthi, M., \& Budiartha, K. (2015). Pengaruh profesionalisme, etika profesi, independensi, dan motivasi kerja, pada kinerja internal auditor. e-Jurnal Akuntansi Universitas Udayana , 10 (3), 797-809.

Wuryano. (2007). the 21 principle to build and develop fighting spirit. Jakarta: PT. ELEX MEDIA KOMPUTINDO.

Yusoff, A. S. (2003). Konsep teori, dimensi dan isu pembangunan. Johor Darul Ta'lim: Universiti Teknologi Malaysia. 